\title{
Development of Picture Card Learning Media to Improve Sexual Understanding in Group B Kindergarten Children
}

\author{
Widiarsini, N. M. $\mathbf{P}^{1 *}$, Ujianti, P.R ${ }^{2}$, Magta. $\mathbf{M}^{3}$ iD \\ 1,2,3 Universitas Pendidikan Ganesha, Singaraja, Indoensia \\ *Corresponding author: putriwidi227@gmail.com
}

\begin{abstract}
Abstrak
Maraknya kasus kekerasan seksual yang terjadi pada anak dibawah umur menyebabkan korban menimbulkan reaksi negatif seperti malu, marah, benci, tersinggung, dan gangguan psikis. Penelitian ini bertujuan untuk media pembelajaran kartu bergambar yang layak digunakan sebagai alat untuk meningkatkan pemahaman seksual pada anak usia dini. Jenis penelitian ini adalah penelitian pengembangan. Model yang digunakan dalam penelitian yaitu model ADDIE yang terdiri dari lima langkah yaitu analis, desain, pengembangan, implementasi, dan evaluasi. Teknik yang digunakan dalam mengumpulkan data yaitu observasi, wawancara, dan kuesioner. Instrument yang digunakan untuk mengumpulkan data adalah kuesioner. Metode analisi data yang digunakan yaitu teknik analisis deskriptif kuantitatif. Uji validitas ahli materi dilakukan dengan 1 orang ahli materi dan 1 orang ahli media pembelajaran. Hasil penelitian yaitu penilaian yang diberikan oleh ahli materi pelajaran dan media pembelajaran, media gambar yang dikembangkan mendapatkan kualifikasi sangat baik. Dapat disimpulkan bahwa media pembelajaran kartu bergambar layak digunakan sebagai media pembelajaran karena dapat meningkatkan semangat dan motivasi siswa dalam belajar sehingga dapat meningkatkan pemahaman anak mengenai seksual. Implikasi penelitian ini yaitu media yang dikembangkan dapat digunakan oleh guru dalam meningkatkan pemahaman seksual pada anak usia dini.
\end{abstract}

Kata kunci: Kartu Bergambar, Pemahaman Seksual

\section{Abstract}

The rise of cases of sexual violence that occurs in minors causes victims to cause negative reactions such as shame, anger, hatred, offense, and psychological disorders. This study aimed to use picture card learning media to increase sexual understanding in early childhood. This type of research was development research. The model used in the study was the ADDIE model, which consisted of five steps, analysis, design, development, implementation, and evaluation. The techniques used in collecting data were observation, interviews, and questionnaires. The instrument used to collect data was a questionnaire. The data analysis method used was the descriptive quantitative analysis technique. The material expert validity test was carried out with one material expert and one learning media expert. The study results were the assessments given by subject matter and learning media experts. The image media developed were very well qualified. It could be concluded that the picture card learning media was appropriate to be used as a learning media because it could increase students' enthusiasm and motivation in learning to increase children's understanding of sexuality. This research implied that the developed media could be used by teachers in increasing sexual understanding in early childhood.

Keywords: Flashcards, Sexual Understanding

\begin{tabular}{ll}
\hline History: & Publisher: Undiksha Press \\
Received : January 27,2021 & Licensed: This work is licensed under \\
Revised $:$ February 05,2021 & a Creative Commons Attribution 3.0 License \\
Accepted : March 10, 2021 &
\end{tabular}

\section{Introduction}

The number of cases of sexual violence that occurs in minors is a very worrying problem and can be said to be in a critical and emergency condition (Irmayani, 2019; Suryani, 2016). The number of sexual violence in Indonesia tends to increase every year. Based on the data center and the Indonesian National Child Protection Commission (KNPAI), from 2010 to 2014, there were 21,869,797 cases of child rights violations spread across 34 provinces, 179 regencies, and cities. As many as $42-58 \%$ of these violations are cases of sexual crimes against children. In 2012 there were 2637 cases (62\% were sexual crimes), and in 2013 there was a fairly large increase in cases, 3339 cases with $62 \%$ sexual 
crimes. Meanwhile, in 2014 (January-April), there were 600 cases or 876 victims (Aziz, 2015). Based on Witness and Victim Protection Agency (LPSK), the increase in cases of sexual violence against children in 2016 has occurred 25 cases, in 2017 with 81 cases, in 2018 206, and at most, in 2019 there were 350 cases (Alfons, 2019).

Sexual harassment is all forms of behavior that leads to sexual things that are carried out unilaterally and are not expected by the person who is the victim, causing negative reactions such as shame, anger, hatred, offense, psychological disorders, and so on (Elvandari \& Chan, 2018; Kurnianingsih, 2015). The forms of sexual harassment itself are very broad, including flirting, naughty whistles, comments with sex or gender connotations, pornographic humor, pinches, pokes, clapping or touching certain body parts, certain movements, or gestures of a sexual nature, sodomy, to rape. So that sexual education for every human being must be done so that there are no more cases of sexual harassment. Sexual education can be given to early childhood. Early childhood is a group of children in a unique growth and development process (Dewi, Tirtayani, \& Suniasih, 2019; Suastariyani \& Tirtayani, 2020). This age is very decisive in the formation of a child's character and personality. Early age is when children experience rapid development and growth (Dista, 2020; Yuniarni, Sari, \& Atiq, 2020). Children at this age are still vulnerable to acts of sexual violence because their condition is still innocent. They do not understand sexuality, so they tend to be obedient and still have great fear and do not have sufficient ability to fight back.

Based on the number of cases of sexual violence that occur in children, it is very necessary to prevent it to reduce the number of sexual violence. One of them is understanding children regarding sexuality (Sulistiani, 2016; Tampubolon, Nurani, \& Meilani, 2019). The understanding of sex given to children will greatly affect the lives of children when they are teenagers. It will even greatly affect their early age. Teaching about sex to children must be given so that children do not get information from wrong sources. Children learning about sex education is as important as children learning cognitive development, social development, and independence (Jatmikowati, Angin, \& Ernawati, 2015; Kurnia \& Tjandra, 2012). The introduction of sexual education is very necessary to build a better future for children. Providing knowledge about sex will help them understand which behaviors are classified as sexual harassment or not, so that sex education can also prevent children from becoming victims of sexual harassment (Irsyad, 2019; Soesilo, 2021).

Sexual education is nothing but the delivery of information regarding the introduction (name and function) of body parts, understanding of gender differences, description of sexual behavior (relationships and intimacy), as well as knowledge of scores and norms that exist in society related to gender (Alfiyah, Solehati, \& Sutini, 2018; Insiyah \& Hidayat, 2020). So sexual understanding is a process of understanding the cognitive domain, explaining, characterizing, and giving examples of sexual behavior. Discussing the problem of sex in children is not easy. It is because the public perception of sex education in children is still considered taboo. Parents see that it is only appropriate to give to children who have grown up or at least teenagers (Chomaria, 2012; Zubaedah, 2016). Parents' concerns are the reason not to teach sex, especially to early childhood. They are afraid that this will trigger the child's curiosity to try to do these sexual activities. In addition to this, teachers in schools also still have a low perception of sexual education (Felicia \& Pandia, 2017). However, providing sexual understanding to children can be helped through the use of learning media.

Learning media is a tool used to help the learning process. Learning media can present messages and stimulate students to learn, examples of books, films, and cassettes used to channel messages (Gunawan et al, 2017; Maqfiroh, Khutobah, \& Budyawati, 2020; Yusnia, 2019). One of the learning media that can help improve sexual understanding in children is picture card learning media (Anggreni, Asri, \& Ganing, 2017; Nida, Parmiti, \& Sukmana, 2020). Picture card media is media made of thick cardboard, patterned in a card, and pasted 
with pictures related to learning materials (Pertiwi, Sumarno, \& Dwi, 2019; Pratita, 2014). The use of picture card media has several advantages, including 1) it is concrete (more realistically shows the subject matter compared to verbal media alone), 2) pictures can overcome space and time constraints, 3) picture card media can clarify a problem, 4) affordable prices and easier to obtain. Learning activities using picture card media are very good for raising students' enthusiasm for learning, training students' sensitivity to an object and stimulating imagination so that it is easy to recognize objects around them (Wasilah, 2012).

Previous research stated that after being given the introduction of early sex education through illustrated story media, there was an increase compared to before being given the introduction of the media (Oktarina \& Liyanovitasari, 2019). The findings of previous studies also state that learning videos can increase knowledge of sexuality in early childhood (Sholikah, Kuswadi, \& Sujana, 2018). Other studies have also stated that book media can increase understanding of sex in early childhood (Fitriani, Fajriah, \& Wardani, 2021). Based on this research, it can be concluded that learning media can improve early childhood understanding of sex. There has been no in-depth study on the development of picture card media that can improve sexual understanding in early childhood. This study aims to develop a sexual understanding of picture card media appropriate for being used as a learning media for children in group B Kindergarten. It is hoped that the developed picture card media can improve early childhood understanding of sex.

\section{Methods}

This research was a type of research and development. The development was carried out on the learning media for sexual understanding picture cards for children in group B in Kindergarten. The development design used in this study adopts the ADDIE development model, which consisted of five stages: analysis, design, development, implementation, and evaluation (Sugiyono, 2015). The ADDIE model was chosen because this model was dynamic and supports program performance. The ADDIE model consisted of five interrelated components and is structured systematically. From the beginning to the end of its application, it must be systematic and cannot be ordered randomly. These five stages or steps were very simple when compared to other design models. It was simple and systematically structured, so this design model was easy to understand and applied. Based on the ADDIE development model (Analysis, Design, Development, Implementation, Evaluation), the development procedure carried out in the study followed the following steps.

The first stage was the analysis stage. At the analysis stage, the researchers analyzed the availability of learning media in schools, especially related to sexual understanding and how teachers perceive sexual education for children in schools. The analysis results obtained that the availability of learning media related to sexual understanding in schools was still limited. In contrast, teachers' perceptions of sexual education were still low, so learning about sexuality was still minimal. The second stage was the design stage. It carried out by the researcher includes: a) formulating learning objectives, b) formulating material items, c) compiling evaluation instruments, d) collecting objects and assembling media, e) expert validation, validation was carried out with material experts and media experts, validation Experts were conducted to determine the feasibility of the content of the material used, while media validation was carried out to determine the level of feasibility of the developed media. The third stage was development. The development stage was carried out to improve learning media after going through an expert validation process to ensure that the developed media was tested and carried out according to input from media and material experts.

The fourth stage was implementation. The implementation stage was the product trial stage in the field. The media with sexual understanding picture cards were tested on group B 
Kindergarten children to determine the feasibility and effectiveness of the media in the learning process. The fifth stage was evaluation. The evaluation stage was the final refinement stage. The evaluation stage was carried out based on field trials' results to obtain a picture card learning media that deserved to be used as a media to increase the sexual understanding of group B kindergarten children. The techniques used in collecting data were observation, interviews, and questionnaires. The data collection instrument used in this study was a questionnaire. Questionnaires were used to measure the quality of the learning media developed. The questionnaire instrument in this study was divided into two, the media expert validation instrument and the material expert validation instrument. The research instrument used a Likert scale with five alternative answers: very good, good, quite good, enough, and not good.

The material expert's instrument grid was made with four assessment aspects with 14 assessment indicators. Meanwhile, the media expert instrument was made with four assessment aspects with 27 assessment indicators. After the preparation of the instrument grid, it was continued with the preparation of the material and media validity test sheets. The assessment on the validity test sheet used a Likert scale. The results of the assessment instrument preparation of the expert consulted with the supervisor to obtain suggestions and input. After making improvements to the instrument, then proceed with testing the validity of media experts and material experts. The data analysis method used was the descriptive quantitative analysis technique. The material expert validity test was carried out with one expert lecturer, and a media expert was also carried out with one expert lecturer who had expertise in their field. After each expert lecturer fills out the validity test sheet, the total average score was calculated, which was still in the form of numbers, then converted using a quantitative to qualitative data conversion table to get the final result.

\section{Results and Discussion}

The development of learning media for sexual understanding illustrated cards was carried out using the ADDIE development model by going through 5 stages, analysis, design, development, implementation, and evaluation. However, due to the COVID-19 emergency, some stages cannot be carried out, the implementation stage and the evaluation stage. The analysis stage carried out in this study was to analyze the availability of learning media in schools, especially related to sexual understanding and how teachers perceive sexual education in children at school. The analysis results obtained are the availability of learning media related to sexual understanding in schools is still limited. The only media available are learning media such as blocks, legos, and puzzles so that they do not have learning media for sexual understanding. Teachers' perceptions of sexual education in schools are also still low, so that sex education in schools has not been carried out.

The design stage in this study was carried out through several stages: 1) Formulating the learning objectives to be achieved, increasing sexual understanding in children in group B Kindergarten. 2) Formulating the points of sexual understanding material that was carried out by consulting with the supervisor and looking at journal references related to considering the child's age. Therefore, the contents of the material on sexual understanding in group B children summarized into 4 indicators, the introduction of body parts (which others may and may not touch, knowing the functions and how to care for the body parts), the introduction of the names of family members and the introduction of other people around them (aimed so that children can be more careful when interacting with people other than their own family), recognition of gender or gender differences, and the role of children in the family and community. 3) Develop evaluation instruments. Material experts and media experts were made in a questionnaire that used the type of answer in a checklist $(\sqrt{ })$. This checklist was used because the researcher assesses it was simpler and easier to provide an assessment. The 
material expert instrument covers four aspects with 14 items of assessment elements. While the media expert instrument consists of 9 aspects with 27 items of assessment elements. 4) Object collection and media design. The objects collected were pictures according to the content of the material downloaded from various sources. The size of the card was $8 \times 12 \mathrm{~cm}$. The material used was HVS laminating paper. This material was used because the author considers the material easier to obtain and does not require too much cost. The selection of the image's color of the image card and the selection of the type, color, and font was used. After that, all the objects that have been collected were assembled into the form of a picture card.

The making of this media card was made using Microsoft Office Word. Then the media was printed using HVS paper which was laminated to make it stronger and more durable. 5) Perform expert validation. The next process was conducting expert validation with material expert lecturers and media expert lecturers. Then the validity data obtained from the results of the assessment by expert lecturers. The assessment results obtained for the content of understanding material are an overall average of 4, while media experts have an overall average of 3.83 with the criteria of "good". The development stage carried out was developing learning media following the results of expert validation, changing the distance between the text and the image, and changing the color of the text to match the background color of the image card. Media development was carried out so that researchers' picture card learning media was ready to be tested. The following was the final display of the picture card learning media after improvements have been made according to suggestions by expert lecturers. In this study, the validity of the material and media was tested with one expert lecturer each. Based on the calculation results, the material validity test obtained an average score of 4 with the "appropriate" category. At the same time, the media validity test obtained an average score of 4.13 with the "very good" category. The calculation of the validity of the material and media can be seen in the table below.

Table 1. Material Validity Test Result

\begin{tabular}{clccccc}
\hline No & \multicolumn{1}{c}{ Aspect } & $\boldsymbol{\Sigma}$ Number & $\boldsymbol{\Sigma}$ Score & Average & Criteria \\
\hline 1 & Relevance & 6 & 24 & 4 & Good \\
2 & $\begin{array}{l}\text { Accuracy } \\
3\end{array}$ & 2 & 8 & 4 & Good \\
$\begin{array}{l}\text { Material equipment } \\
\text { The suitability of the } \\
\text { presentation with the demands of } \\
\text { learning that must be mastered } \\
\text { by children }\end{array}$ & 4 & 8 & 4 & Good \\
\multicolumn{1}{c}{ Total } & & 16 & 4 & Good \\
\hline & Average & $\mathbf{1 4}$ & $\mathbf{5 6}$ & $\mathbf{1 6}$ & Good \\
\hline
\end{tabular}

Table 2. Media Validity Test Results

\begin{tabular}{clcccc}
\hline No & \multicolumn{1}{c}{ Aspect } & $\boldsymbol{\Sigma}$ Number & $\boldsymbol{\Sigma}$ Score & Average & Criteria \\
\hline 1 & Keterbacaan Kata & 3 & 13 & 4,33 & Very good \\
2 & Kualitas Gambar & 3 & 14 & 4,67 & Very good \\
3 & Keserasian Warna & 3 & 11 & 3,67 & Good \\
4 & Penggunaan Garis & 1 & 4 & 4 & Good \\
5 & Bentuk & 1 & 4 & 4 & Good \\
6 & Tekstur & 1 & 4 & 4 & Good \\
7 & Ruang atau space & 3 & 12 & 4 & Good \\
8 & Bahan & 1 & 4 & 4 & Good
\end{tabular}




\begin{tabular}{cccccc}
\hline No & Aspect & $\boldsymbol{\Sigma}$ Number & $\boldsymbol{\Sigma}$ Score & Average & Criteria \\
\hline 9 & Penggunaan Media & 11 & 50 & 4,54 & Very good \\
\hline & Total & $\mathbf{2 8}$ & $\mathbf{1 1 6}$ & $\mathbf{3 7 , 2 1}$ & \multirow{2}{*}{ Very good } \\
\hline & Average & & $\mathbf{4 , 1 3}$ & \\
\hline
\end{tabular}

Based on the results of the calculations in the table above, it can be concluded that the learning media for sexual understanding picture cards has a quality that is appropriate to be used as a learning media in the classroom to help improve sexual understanding in children in group B Kindergarten. Picture card learning media is good to be used as a learning media. It is caused by several factors, as follows. First, the picture card learning media deserves to be used as a learning media because it can increase students' enthusiasm and motivation. Learning media that are packaged attractively can increase students' enthusiasm for learning (Herayanti, Habibi, \& Fuaddunazmi, 2017; Sunismi, 2015). Picture card media was packaged very attractively, which presents images according to the characteristics of early childhood so that children are very enthusiastic about learning. In addition, the selection of colors on the cards also makes students feel interested in using these picture cards as learning media. Second, the picture card learning media deserves to be used as a learning media because it can improve children's understanding of learning. Packaging instructional media according to student characteristics will make it easier for students to understand the material presented in learning media (Puspitorini, Subali, \& Jumadi, 2014; Qumillaila, Susanti, \& Zulfiani, 2017). The developed picture card media was packaged according to the characteristics of students, and the images presented also make it easier for students to understand the learning material. The picture card media that was developed succeeded in increasing the understanding of early childhood because it stimulated children to be active. It can be seen when applying picture card media. Children are very active in playing and learning, so that this media can also increase the enthusiasm of children in learning.

Previous research also stated that after being given the introduction of early sex education through the media of picture stories, there was an increase compared to before being given media introduction (Oktarina \& Liyanovitasari, 2019). Other research states that learning video media can foster creativity in early childhood (Prahesti, Taulany, \& Dewi, 2020). Previous research on image media stated that image media could increase the potential for children's speech development and increase vocabulary mastery (Aprinawati, 2017). It can be concluded that the use of media can improve students' understanding of learning. This research implies that the developed media can be used by teachers in improving students' understanding of learning. Improving sexual understanding in children requires learning media, both picture card learning media and other supportive learning media. With the help of learning media, it will also make it easier for teachers to deliver material and improve learning outcomes.

\section{Conclusion}

Based on the results of data analysis, assessments carried out by subject matter experts, and learning media, the developed image media obtained very good qualifications. It can be concluded that the picture card learning media is good to be used as a learning media because it can increase the enthusiasm and motivation of students in learning so that it can improve children's understanding of learning.

\section{References}

Alfiyah, N., Solehati, T., \& Sutini, T. (2018). Gambaran Faktor-Faktor yang Berhubungan dengan Perilaku Seksual Pranikah pada Remaja SMP. Jurnal Pendidikan 
https://doi.org/https://doi.org/10.17509/jpki.v4i2.10443.

Alfons, M. (2019). LPSK: Kasus Kekerasan Seksual pada Anak Meningkat Tiap Tahun. Detik News.

Anggreni, P. F., Asri, I. A. S., \& Ganing, N. N. (2017). Pengaruh Model Pembelajaran Kooperatif Tipe Think- Pair-Share ( Tps ) Berbantuan Media Kartu Bergambar Terhadap Penguasaan Kompetensi Pengetahuan Ips Siswa Kelas V Gugus Letkol Wisnu. Mimbar PGSD, https://doi.org/http://dx.doi.org/10.23887/jjpgsd.v5i2.10645.

Aprinawati, I. (2017). Penggunaan Media Gambar Seri Untuk Meningkatkan Kemampuan Berbicara Anak Usia Dini. Jurnal Obsesi : Jurnal Pendidikan Anak Usia Dini, 1(1). https://doi.org/https://doi.org/10.31004/obsesi.v1i1.33.

Aziz, S. (2015). Pendidikan seks anak berkebutuhan khusus. Yogyakarta: Gava Media.

Chomaria, N. (2012). Pendidikan seks untuk anak. Aqwam.

Dewi, N. P. A. S., Tirtayani, L. A., \& Suniasih, N. W. (2019). Efektivitas Program Paud Inklusi Di Kota Denpasar Ditinjau Dari Aspek Konteks. Jurnal Pendidikan Anak Usia Dini Undiksha, 7(1). https://doi.org/http://dx.doi.org/10.23887/paud.v7i1.18731.

Dista. (2020). Manajemen Pendirian Taman Kanak-Kanak (Studi Kasus Di TK Fastrack Funschool Yogyakarta). Jurnal Pendidikan Anak Usia Dini Undiksha, 8(2), 101-111. https://doi.org/http://dx.doi.org/10.23887/paud.v8i2.22582.

Elvandari, S., \& Chan, M. L. (2018). A Patient's Legal Protection as a Victim of Sexual Harassment on Medical Services in Indonesia. Jurnal Cita Hukum, 6(2). https://doi.org/https://doi.org/10.15408/jch.v6i2.8684.

Felicia, uliette P., \& Pandia, W. S. S. (2017). Persepsi Guru Tki Terhadap Pendidikan Seksual Anak Usia Dini Berdasarkan Health-Belief Model. Jurnal Pendidikan Anak, 6(1). https://doi.org/https://doi.org/10.21831/jpa.v6i1.15682.

Fitriani, D., Fajriah, H., \& Wardani, A. (2021). Mengenalkan Pendidikan Seks Pada Anak Usia Dini Melalui Buku Lift The Flap "Auratku." Gender Equality, 7(1). https://doi.org/http://dx.doi.org/10.22373/equality.v7i1.8683.

Gunawan, G., Sahidu, H., Harjono, A., \& Suranti, N. M. Y. (2017). The effect of project based learning with virtual media assistance on student's creativity in physics. Jurnal Cakrawala Pendidikan, 1(2). https://doi.org/https://doi.org/10.21831/cp.v36i2.13514.

Herayanti, L., Habibi, H., \& Fuaddunazmi, M. (2017). Pengembangan Media Pembelajaran Berbasis Moodle pada Matakuliah Fisika Dasar. Jurnal Cakrawala Pendidikan, 36(2), 210-219. https://doi.org/10.21831/cp.v36i2.13077.

Insiyah, N. S., \& Hidayat, S. (2020). Kajian Tentang Komunikasi Orang Tua Dalam Pendidikan Seks Untuk Anak Sekolah Dasar. Pendadikta: Jurnal Ilmiah Mahasiswa Pendidikan Guru Sekolah Dasar, 7(2). Retrieved from https://ejournal.upi.edu/index.php/pedadidaktika/article/view/25342.

Irmayani, N. R. (2019). Problematika Penanganan Terhadap Anak Pelaku Tindak Kekerasan Seksual Selama Menjalankan Proses Hukum (Kasus Di Provinsi Kalimantan Barat). Sosio Konsepsia: Jurnal Penelitian Dan Pengembangan Kesejahteraan Sosial, 8(3). https://doi.org/https://doi.org/10.33007/ska.v8i3.1795.

Irsyad, M. (2019). Pendidikan Pendidikan Seks Untuk Anak Usia Dini. Elementary: Jurnal Ilmiah Pendidikan Dasar, 5(1). https://doi.org/https://doi.org/10.32332/elementary.v5i1.1374.

Jatmikowati, T. E., Angin, R., \& Ernawati, E. (2015). Model Dan Materi Pendidikan Seks Anak Usia Dini Perspektif Gender Untuk Menghindarkan Sexual Abuse. Cakrawala Pendidikan, 3(3). https://doi.org/https://doi.org/10.21831/cp.v3i3.7407.

Kurnia, N., \& Tjandra, E. (2012). Bunda, Seks itu apa sih. Cara Cerdas Dan Bijak 
Menjelaskan Seks Pada Anak, Jakarta, PT Gramedia Pustaka Utama.

Kurnianingsih, S. (2015). Pelecehan Seksual Terhadap Perempuan Di Tempat Kerja. Buletin Psikologi, 11(2). https://doi.org/https://doi.org/10.22146/bpsi.7464.

Maqfiroh, Khutobah, \& Budyawati. (2020). Pengembangan Media MOTIF (Monopoli Edukatif) dalam Pembelajaran berbasis Multiple intelligence. Cakrawala Dini: Jurnal Pendidikan Anak Usia Dini, 11(1), 64-74. Retrieved from https://ejournal.upi.edu/index.php/cakrawaladini/article/view/24230/12062.

Nida, Parmiti, \& Sukmana. (2020). Pengembangan Media Kartu Bergambar Berorientasi Pendidikan Karakter Pada Mata Pelajaran Bahasa Bali. Jurnal EDUTECH Universitas Pendidikan Ganesha., 8(1), 16-31. Retrieved from https://ejournal.undiksha.ac.id/index.php/JEU/article/view/25393/15846.

Oktarina, N. D., \& Liyanovitasari, L. (2019). Media Cerita Bergambar Tentang Pengenalan Seks Dini Meningkatkan Pengetahuan Anak Usia Dini. Jurnal Kesehatan Perintis (Perintis's Health Journal), 6(2), 110-115. https://doi.org/https://doi.org/10.33653/jkp.v6i2.296.

Pertiwi, I. N., Sumarno, \& Dwi, A. (2019). Pengaruh Model Make A Match Berbantu Media Kartu Bergambar terhadap Kemampuan Membaca dan Menulis. E-Journal PGSD Pendidikan Ganesha Mimbar PGSD, 7(3), 261-270. https://doi.org/http://dx.doi.org/10.23887/jjpgsd.v7i3.19412.

Prahesti, wantyka I., Taulany, H., \& Dewi, N. K. (2020). Gerak dan Lagu Neurokinestetik (GELATIK) untuk Menumbuhkan Kreativitas Seni Anak Usia Dini. Jurnal Obsesi : Jurnal Pendidikan Anak Usia Dini, https://doi.org/https://doi.org/10.31004/obsesi.v4i1.289.

Pratita, D. (2014). Penggunaan Media Kartu Gambar Untuk Meningkatkan Hasil Belajar Ekonomi Di SMP. PARAMETER: Jurnal Pendidikan Universitas Negeri Jakarta, 25(2), 86-94. https://doi.org/https://doi.org/10.21009/parameter.252.04.

Puspitorini, Subali, \& Jumadi. (2014). Penggunaan Media Komik Dalam Pembelajaran IPA Untuk Meningkatkan Motivasi Dan Hasil Belajar Kognitif Dan Afektif. Cakrawala Pendidikan, 33(3), 413-420. Retrieved from https://journal.uny.ac.id/index.php/cp/article/view/2385/pdf.

Qumillaila, Susanti, \& Zulfiani. (2017). Pengembangan Augmented Reality Versi Android Sebagai Media Pembelajaran Sistem Ekskresi Manusia. Cakrawala Pendidikan, 34(1), 57-69. Retrieved from https://journal.uny.ac.id/index.php/cp/article/view/9786/pdf. \%0A.

Sholikah, M. M., Kuswadi, K., \& Sujana, Y. (2018). Penggunaan Video Pembelajaran Untuk Meningkatkan Pengetahuan Seksualitas Pada Anak Kelompok B2 Tk Islam Permata Hati Makam Haji Kabupaten Sukoharjo Tahun Ajaran 2015/2016. Jurnal Kumara, 6(3). https://doi.org/https://doi.org/10.20961/kc.v6i3.35134.

Soesilo, T. D. (2021). Pelaksanaan Parenting Pendidikan Seks (Pesek) Anak Usia Dini di PAUD Tunas Bangsa Ungaran Kabupaten Semarang. Scholaria : Jurnal Pendidikan Dan Kebudayaan, 1(1). https://doi.org/https://doi.org/10.24246/j.js.2021.v11.i1.p4753.

Suastariyani, N. K. N., \& Tirtayani, L. A. (2020). Survei Persepsi Orang Tua Mengenai Program Paud Inklusi Di Kota Denpasar Tahun 2020. Jurnal Pendidikan Anak Usia Dini Undiksha, 8(2). https://doi.org/http://dx.doi.org/10.23887/paud.v8i2.25156.

Sugiyono. (2015). Metode Penelitian Pendidikan. Bandung: Alfabeta.

Sulistiani, S. L. (2016). Konsep Pendidikan Anak Dalam Islam Untuk Mencegah Kejahatan Dan Penyimpangan Seksual. Ta'di Jurnal Pendidikan Islam, 5(1). https://doi.org/https://doi.org/10.29313/tjpi.v5i1.1998.

Sunismi. (2015). Developing Guided Discovery Learning Materials Using Mathematics 
Mobile Learning Application As An Alternative Media For The Students Calculus II. Cakrawala Pendidikan, 34(3), 334-346. https://doi.org/https://doi.org/10.21831/cp.v3i3.7340.

Suryani, A. M. (2016). Mengapa Anak Bungkam Atas Pengalaman Kekerasan Seksual? Syndrom Penyesuian Diri Roland Summit: Implementasi Di Indonesia. Buletin Psikologi, 17(1). https://doi.org/https://doi.org/10.22146/bpsi.11481.

Tampubolon, G. N., Nurani, Y., \& Meilani, S. M. (2019). Pengembangan Buku Pendidikan Seksual Anak Usia 1-3 Tahun. Jurnal Obsesi, 3(2). https://doi.org/https://doi.org/10.31004/obsesi.v3i2.243.

Wasilah, E. B. (2012). Peningkatan kemampuan menyimpulkan hasil praktikum ipa melalui penggunaan media kartu. Jurnal Pendidikan IPA Indonesia, 1(1). https://doi.org/https://doi.org/10.15294/jpii.v1i1.2018.

Yuniarni, Sari, \& Atiq. (2020). Pengembangan Multimedia Interaktif Video Senam Animasi Berbasis Budaya Khas Kalimantan Barat. Jurnal Obsesi : Jurnal Pendidikan Anak Usia Dini, 4(1). https://doi.org/https://doi.org/10.31004/obsesi.v4i1.331.

Yusnia, Y. (2019). Penggunaan Media Video Scribe Dalam Pembelajaran Literasi Sains Untuk Mahasiswa PGPAUD. Cakrawala Dini: Jurnal Pendidikan Anak Usia Dini, 10(1), 71-75. https://doi.org/https://doi.org/10.17509/cd.v10i1.17436.

Zubaedah, S. (2016). Pendidikan seks pada anak usia dini di taman kanak-kanak (TK) Islam kota Yogyakarta. Al-Athfal: Jurnal Pendidikan Anak, 2(2), 55-68. Retrieved from http://ejournal.uin-suka.ac.id/tarbiyah/index.php/alathfal/article/view/1267. 